\title{
Firm Size and Employment Dynamics
}

\author{
Maria Canon, Economist \\ Yang Liu, Senior Research Associate
}

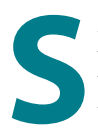

mall employers (firms with fewer than 50 employees) have been fundamental to employment growth in the United States, particularly during recessions. In their 2012 study, Moscarini and Postel-Vinay use 1978-2009 data and find that job flows at large employers are more cyclical. In particular, large firms, on net, destroy proportionally more jobs than small employers when unemployment is above trend (i.e., late in a recession and immediately after a recession) and create more jobs when unemployment is below trend (i.e., late in a typical expansion). The authors find that this disparity is due to different patterns of entry and exit for large and small employers and that it also holds for employers of different ages. Has the recovery from the Great Recession followed similar patterns?

The table shows the share of job gains and job losses by firm size (small firms, 1-49 employees; medium firms, 50-499 employees; large firms, $500+$ employees) ${ }^{1}$ for recession years and for the years before and after the past two recessions. In 2001 and 2009 (recession years), the evidence is largely consistent with the findings of Moscarini and Postel-Vinay. However, early in the recovery from the Great Recession, when unemployment was still elevated, the data do not follow this pattern as strongly.

Medium firms' share of total job gains has been shrinking since the 1990s. It fell from 25.13 percent during the
1993-2000 period to 23.44 percent in 2009. During the current expansion, medium firms' share of total job gains recovered slightly to 23.55 percent. Large firms' share of total job gains has also been on a declining trend since 1993: It was 23.32 percent during the 1993-2000 period but fell to 23.05 percent during the 2001 recession and to 22.19 percent during the 2002-07 expansion. The share fell to 20.25 percent in 2009 during the Great Recession. However, during the 2010-13 period, large firms' share of total job gains increased rapidly to 23.48 percent.

We find, consistent with the results of Moscarini and Postel-Vinay, that small firms created a higher fraction of new jobs and destroyed a smaller fraction of jobs late in the recessions of 2001 and 2009. Our data show that small firms' share of total job gains followed an upward trend until the most recent economic expansion: Small firms accounted for 51.55 percent of total job creations in the 1993-2000 period; this share increased to 52.69 percent during the 2001 recession and to 53.73 during the 2002-07 expansion. The share increased significantly to 56.31 percent in 2009 during the Great Recession. However, our observations show that in the four years after the Great Recession (2010-13), the share of jobs created by small firms decreased to 52.97 percent even though unemployment was still above trend; therefore, given this environment,

\section{Job Gains and Losses by Firm Size}

\begin{tabular}{|c|c|c|c|c|c|c|}
\hline \multirow[b]{2}{*}{ Years } & \multicolumn{3}{|c|}{ Job gains (\%) } & \multicolumn{3}{|c|}{ Job losses (\%) } \\
\hline & Small firms & Medium firms & Large firms & Small firms & Medium firms & Large firms \\
\hline $1993-2000$ & 51.55 & 25.13 & 23.32 & 53.86 & 24.69 & 21.45 \\
\hline $2002-07$ & 53.73 & 24.08 & 22.19 & 54.41 & 23.87 & 21.72 \\
\hline 2008 & 54.95 & 24.00 & 21.05 & 52.82 & 23.54 & 23.64 \\
\hline
\end{tabular}

SOURCE: Bureau of Labor Statistics, Business Employment Dynamics database. ${ }^{2}$ 
the large firms would be expected to create a smaller share of jobs.

Job losses did indeed follow similar patterns during and after the Great Recession, just as they did during and after the 2001 recession. Our data show that the share of jobs lost closely follows the cyclical pattern found by Moscarini and Postel-Vinay. For example, small firms' share of total job losses was 53.86 percent in the 1993-2000 period. It fell sharply to 48.81 percent during the 2001 recession and rebounded strongly to 54.41 percent in the 2002-07 expansion. Small firms' share of job losses declined again during the Great Recession to 51.71 percent in 2009, but it rebounded strongly to 55.47 percent during the 2010-13 expansion.

\section{Large firms have been creating a significantly higher fraction of jobs since the Great Recession.}

Medium firms' share of total employment losses rose modestly from 24.69 percent in the $1993-2000$ period to 25.40 percent during the 2001 recession; it then fell to 23.87 percent during the 2002-07 expansion. Medium firms' share of job losses was up slightly toward the end of the Great Recession: to 23.93 percent in 2009. However, this minor uptick was followed by a moderate decline, to 22.77 percent, during the 2010-13 recovery.

Large firms accounted for 21.45 percent of total jobs lost in the 1993-2000 period. This share moved up sharply to 25.79 percent during the 2001 recession and returned to 21.72 percent during the 2002-07 expansion.

Recent data suggest that even though large firms' net job destruction (job losses minus job gains) was higher during the Great Recession than during the 2001 recession, these firms have been creating a significantly higher fraction of jobs since the Great Recession than they did after the 2001 recession. In 2013, 25.73 percent of all new jobs (6.154 million jobs) were created by large-sized firms, the highest fraction since 1993, despite average unemployment of 7.4 percent in 2013 (significantly higher than the rates in the 1993-2007 period). These new patterns might have implications for other labor market variables such as wage growth.
In studies along the lines of Moscarini and Postel-Vinay, the labor market tightens after a recession. Therefore, larger firms can hire new employees only by poaching them from smaller-and plausibly less productive-firms whose employment share then shrinks. The labor market took significantly longer to recover after the Great Recession, and there was a larger pool of unemployed workers for an abnormally long time. Large firms could continue to hire from the pool of unemployed workers and did not need to poach from smaller firms. Because poaching offers and wage gains are often linked, this feature of labor dynamics is also consistent with the slow wage inflation observed since the Great Recession.

\section{NOTES}

\footnotetext{
1 Moscarini and Postel-Vinay classify firms with at least 1,000 employees as large firms.

2 The Business Employment Dynamics data series, published by the Bureau of Labor Statistics, decomposes the U.S. net employment change into gross job gains and gross job losses. The gross job gains and losses are also disaggregated by firm size.
}

\section{REFERENCE}

Moscarini, Giuseppe and Postel-Vinay, Fabien. "The Contribution of Large and Small Employers to Job Creation in Times of High and Low Unemployment." American Economic Review, October 2012, 102(6), pp. 2509-39. 